\title{
RISE AND DECLINE OF THE ROCK ISLAND PASSENGER TRAIN IN THE 20TH CENTURY
}

\author{
by Paul C. Nelson \\ Roland, lowa
}

PART II

Part I of the "Rise And Decline Of The Rock Island Passenger Train In the 20th Century" appeared in the Summer, 1971, issue of the ANNALS.

A major development in 1961 regarding the Rock Island Passenger train was the death of John D. Farrington. Farrington passed away on October 13, 1961 at the age of $70 .{ }^{145} \mathrm{He}$ was quite a name in the history of the Rock Island, and especially in the development of its Rockets. This is quite evident by now after reading about Farrington doing this, or Farrington purchasing such and such. He was concerned about the Rock Island and wanted to give it the best image possible, whether it be to add passenger trains or take them off; Farrington, of course, is probably most noted for his introduction of the Rockets in 1937. He had said of the Rockets after they had become successful, "I had Rock Island's reputation to overcome. It was a very bad reputation as to service - both freight and passenger service. Our passenger business was at an all-time low and it seemed to me that a radical departure with the introduction of the streamliners would have the desired effect."146 Farrington did overcome this reputation as Rock Island become noted for its famous Rockets, which were to become among the most famous trains in the country. And indeed, they deserved this distinction, as J. D. Farrington deserved credit for all he did for the Rock Island.

Even though the Rock Island had taken off several trains by 1963, including the former Texas Rocket and several branch lines trains throughout the midwest, they still had trains running on their main routes. In fact, Frank Donovan, a noted railroad writer, described the Rock Island's passenger position in 1963 in the following way: "Unlike some other

145"John D. Farrington Dies," p. 2.

${ }^{146}$ Hayes, Iron Road, p. 240. 


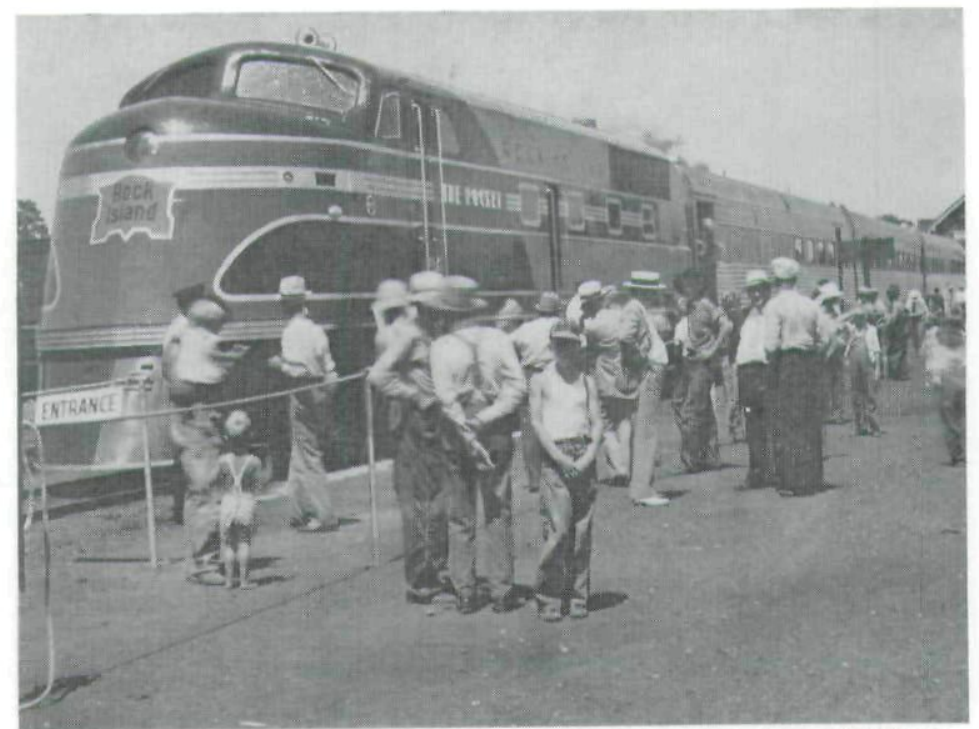

Contesy of Des Moines Register \& Tribune

Ultra-streamlined Rocket just after it pulled into Des Moines, Aug. 10, 1937.

Iowa railroads, the Rock Island is still very much in the passenger business."147 Chicago and Northwestern, for example, had already taken off all its passenger trains between Omaha and Chicago. Also, the Milwaukee Road was running only one train of its own between Omaha and Chicago. Considering Rock Island's financial situation, they did quite well in operating this many passenger trains, with the good quality equipment, for as long as they did.

The major development in 1964 for the Rock Island Line was the naming of Jervis Langdon as chairman, a position vacant since the death of J. D. Farrington in 1961. ${ }^{148}$ He took over as chairman and chief executive on October 8, 1964. Langdon was concerned about the future of the passenger train as will be noted throughout the rest of this paper. He wanted the best to be done for both the railroad and its passengers. When he was president of $\mathrm{B} \& \mathrm{O}$ in 1963, he

${ }^{147}$ Frank Donovan, "Line Relocation and Modernization," The Palimpsest, LXIV (September 1963), 442.

${ }^{148}$ New York Times, 9 October 1964. 
appointed a man to head the passenger department who had not had previous experience with passengers and, thus, no "preconceived" ideas of what could or could not be done. In fact, this new man was to try anything to put passenger business on a profitable basis in terms of out-of-pocket costs by the end of 1965. ${ }^{149}$ Thus, Langdon cannot be called a man who wouldn't try to make passenger trains a success. However, he evidently didn't feel the Rock Island was capable of withstanding the losses of certain passenger trains, as he did take a few drastic steps in the passenger department as we shall later see. Langdon's comment regarding the Rock Island passenger trains shortly after he took over in 1964 was:

If it becomes necessary to drop passenger service for the longer distances, we shall do so reluctantly, but with the firm conviction that the freight service should no longer be asked to absorb the inevitable and growing deficits and that from the point of view of the company's relations with the public, inferior passenger is much worse than no service at

There are several significant points in this statement. First of all, Langdon was realistic about the problem. Certainly, no private company, owned by private parties, should have to pay for money losing ventures that are not needed. Also, Langdon does not say he would like to abandon all passenger trains just for the sake of getting rid of them as some companies seem to have done. Langdon did face up to the reality of the situation, however. "The cold fact is that business travel is now using the airplane, almost exclusively... . While efforts to attract more patronage have been intensified, and we are hopeful the traveling public will respond favorably, it is hard to be optimistic."151 Thus, this is the way it became on American Railroads. In the 60 's, as more and more interstate highways were opened up and jets became cheaper and faster, more and more people turned away from the train.

There was a problem with the personnel attitudes, also, "Some personnel simply didn't care about the passenger. The freight train was the revenue and the passenger train was

149"Fewer-and far between," Business Week, no vol. (September $26,1964), 117$.

${ }^{150}$ Jervis Langdon, jr., "To the Stockholders," Rock Island Lines Annual Report, 1964, p. 4-5.

${ }^{151}$ Ibid., p. 4. 
just there. One guy at the switch tower, for example, just hated passenger trains. He would put them in the 'hole' every time he got the chance." ${ }^{152}$

It is hard to understand why some of these problems or attitudes came about. Evidently some personnel working for the railroad were concerned about money and nothing else. Yet, it is a widely known fact that many people think of the railroad by the kind of passenger trains it runs, and judge it accordingly.

In 1964 a coach seat reservation plan was put into effect on the most heavily used Rock Island passenger trains. The cost of the reservation was $50 \%$. Whether this reservation plan was put into effect to discourage or encourage passengers is debatable, though Rock Island said it was done primarily to provide a more accurate method of determining equipment requirements so passenger cars could be assigned to trains more efficiently. They did add that it was put into effect to bring in more revenue. ${ }^{153}$ Prior to this time, the Rock Island had made special note in its timetables that the Rockets were not extra-fare trains. Even though this seat reservation charge was nominal, it was bound to frustrate some passengers, especially those on short trips.

Discontinued in 1964 were trains 39 and 40 between Kansas City and Rock Island. For the first time in the 20th Century, this left the Golden State Route with only one train. The route of the former Choctaw Rocket was also made a one train per day route in 1964 when the Rock Island discontinued trains 23 and 24 between Memphis and Amarillo. ${ }^{154}$ With the end of this run also came the end of the use of Budd cars. The Budd-RDC cars had been used by the Rock Island on several runs south of Kansas City between 1954 and 1964. It was a fairly common thing to see one at the end of a train, waiting to be dropped at a division point where it could take off on its own. ${ }^{155}$ For some reason, Rock Island never

${ }^{152}$ James Windsor III, personal interview with author, 8 January 1971; 14 January 1971.

${ }^{153}$ Langdon, "To the Stockholders," 1964, p. 8.

${ }^{154}$ Langdon, "To the Stockholders," 1964, p. 8.

155"RDC's that lost their engines," Trains, XXVI (December 1965), 37. 
used Budd cars north of Kansas City. Mr. E. R. Carlson feels the Rock Island should have tried them between Des Moines and Minneapolis, and that, if they would have been properly promoted, there would have been enough volume to make these cars pay. ${ }^{156}$ After the last Budd car ran in 1964, the motors were taken out and in 1965 they were still used between Memphis and Tucumcari as Railway Post Office cars (RPO's) and coaches. The Rock Island had had the distinction of having the longest passenger run by a Budd car for about three years, from 1961 until $1964 .{ }^{157}$

Many changes took place on Rock Island passenger trains in 1965. Nineteen sixty-five may not have been as bad for the passenger train as 1967, but in some ways it seemed worse. The Rock Island still said they were trying, and granted, in some ways they were. However, it is not hard to understand the changes made, considering their financial situation. Jervis Langdon described the 1965 situation thusly: "Rock Island has undertaken a system wide, in-depth study of its passenger operations, and is setting a course which will determine the potential of its travel market and move positively within the bounds of realistic economics to meet the situation." 158 The economic problem Mr. Langdon is referring to here is that the Rock Island reported a net loss of $\$ 1,450,699$ in 1965 , its first losing year since $1940 .{ }^{159}$ What could the Rock Island do? It simply had to cut somewhere, and of course, it couldn't cut freight service where money was being made. Thus, it was the passenger train that was neglected. The passenger train was more and more put in the "hole", or siding, for freights, simply because the freights were the "revenue producers." ${ }^{160}$

With the situation as it was, this writer can conjure up no good argument against the Rock Island's action which was to strip all passenger trains of their sleepers, parlor cars and diners. These changes were put into effect, July 1, 1965. The

${ }^{156}$ E. R. Carlson, interview, 11 January 1971.

157"RDC's that lost their engines," p. 37.

${ }^{158}$ "Sales Agencies Geared to meet needs of Customers," The Rocket, XXIV (March-April 1965), 8.

${ }^{159}$ New York Times, 4 February 1966.

${ }^{160}$ James Windsor, 8 January 1971. 
only train exempted from this action was the Golden State, operated jointly with Southern Pacific. The Rock Island described the situation thusly: "The ever-increasing cost of providing this service (sleeping, dining and parlor) and the declining trend in patronage, coupled with our low financial position, left us no alternative. ${ }^{161}$ What a sad situation it was. Not all food service was taken off, however. Snack-Beverage cars were put on in place of the diners. This new, budget food service offered a variety of sandwiches, pastries and beverages, and prices were considerably lower than conventional dining cars. The Rock Island tried to reconcile themselves for taking off the regular diners in favor of these cars, stating that surveys indicated that Rock Island passengers wanted lower priced meals even if it meant eliminating the atmosphere of the traditional, but costly-to-operate, dining car. ${ }^{162}$ The death toll for 1965 stood as follows: five parlor or lounge cars removed, five dining cars replaced by snack beverage cars, and five sleeping cars removed. The trains affected were: the Des Moines Rocket; the Des Moines to Chicago, \#6; the Rocky Mountain Rocket; the Chicago to Omaha train, \#9; the Corn Belt Rocket; all four Peoria Rockets; 15 and 16 between Minneapolis and Kansas City and the Twin Star Rocket. ${ }^{163}$

There were other developments in the passenger picture in 1965. In April 1965, the Rock Island came out with a new, small timetable. This timetable replaced the traditional railroad-style timetable that had been used since before the turn of the century. The new-style table was put into use for two reasons: To save money and to make an easier reading timetable. ${ }^{164}$ It may have been somewhat easier to read, but, for the most part, was a disappointment. Missing in it were the map of the entire Rock Island system, an index to all Rock Island stations on mainlines, and a listing of train 14.

161"Sleepers discontinued," The Rocket, XXIV (July-August, 1965),

${ }^{162 “}$ "Snack Beverage Cars put on Trains," The Rocket, XXIV (JulyAugust, 1965), 14.

${ }^{163}$ Rock Island Public Timetables, 25 April 1965, p. 10; 31 October 1965 , p. 10.

${ }_{164}$ James Pate, Director of Public Relations, Rock Island Lines, letter, 21 January 1971, to the author. 
connections in Chicago and the Twin Cities. In addition, not as much information on equipment was listed, nor as much information on fares. It also lacked the beautiful picture on the cover of the old timetables, and, to this writer, had a very unattractive pink background with the red Rock Island emblem on the cover.

Since there were so many changes among Rock Island's passenger trains in 1965, this is a fitting time to stop and look at the situation regarding passenger trains through the 60 's thus far. The early 60 's seemed to be a turning point for the Rock Island's passenger trains. In the early 60 's service went down. One retired Rock Island employee thought that it seemed the railroad began to discourage passengers at this time. He also felt the Rock Island lost its desire to run passenger trains of quality. ${ }^{165}$ Many people have felt that the railroads discouraged passengers. Yet it doesn't seem that this was Rock Island's primary intention in dropping this equipment. The dropping of equipment probably did discourage passengers, but the Rock Island was not making money and had to cut losses somewhere. If they simply wanted to discourage passengers, for the sake of discouraging passengers, they could have made more drastic equipment discontinuances sooner. One person put it like this, "I believe their's (Rock Island passenger service) was as good as any until they were plagued by financial trouble"166 ${ }^{16}$, for the most part, the Rock Island maintained good and luxurious service until the public was no longer riding their trains, and the railroad could no longer afford to support trains that didn't pay their way. Yet, there is still the problem that the railroad let their concern for the public and its passenger trains drop. "For example, in the early 50's if a passenger train was due in Chicago at, say $7: 30$ p.m., that train was expected to be there. If the train was delayed any place along the line someone had to answer for that delay. In the 60 's, the management did little about delayed trains." ${ }^{167}$ In fact, the irregularity of schedules was probably the major problem of the Rock Island. "The on-

${ }^{165}$ Leon Richardson, retired Rock Island switchman, Des Moines, personal interview with the author in Des Moines, 19 December 1970.

${ }^{166}$ R. C. Brown, letter, 10 January 1971.

${ }^{167}$ Leon Rchardson, 19 December 1970 
time performance was poor. It was a very dreary affair."168 Yet, the Rock Island could run trains close to schedule if it wanted to, and did so in the $50 \mathrm{~s}$.

In some ways, 1966 was as bad a year for Rock Island passenger trains as was 1965 . Nineteen sixty-six was the year of death for the famed Rocky Mountain Rocket. The ICC, on investigation, said use of the train had dropped from 96 passengers in 1964 to 73.5 in 1965 and to 51.5 the first six months of 1966, and continued operation would result in a loss of about $\$ 488,000$ a year. Relatively few who appeared at the hearing had ridden the trains. ${ }^{169}$ For some strange reason no ICC hearings were held east of Omaha even though this (the Rocky Mountain Rocket) was a through train from Chicago to Denver. ${ }^{170}$ The ICC gave permission to drop the trains between Omaha and Denver and the "Rocket" name was dropped with the name Cornhusker being given to the trains. ${ }^{171}$ There was a problem in regard to the economics of the Rocky Mountain Rocket, however, as with most trains. This problem was the union rules which will be described later on in this paper. Largely because of these out-of-date union rules, it took 55 crewmen to operate the Rocky Mountain Rocket from Chicago to Denver. ${ }^{172}$ It is not hard to understand, then, why the railroad had a hard time of coming out in the black in the operation of the Rocky Mountain Rocket.

Also, in 1966, the Twin Star Rocket between Kansas City and Fort Worth was dropped. Again, there seems to have been some discrepancy on the part of the ICC regarding the need of this train. One commissioner in the original report told of a train needed by the public and downgraded by the railroad, while another commissioner's report told of an unused mail train operating after its time by the good graces of the Rock Island. ${ }^{173}$ There were definite problems somewhere. After permission was granted to drop the trains, the Rock Island did upgrade its service on the remaining part of the Twin

${ }^{168}$ James Windsor III, 8 January 1971.

${ }^{169}$ Wall Street Journal, 12 October 1966.

${ }^{170}$ Steve Wylder, Rock Island railfan, North Liberty, Iowa, letter, 18 January 1971, to the author.

${ }^{171}$ Rock Island passenger Timetables, 30 October 1966.

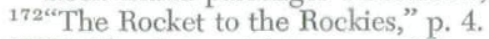

${ }^{173}$ Wylder, letter, 18 January 1971. 


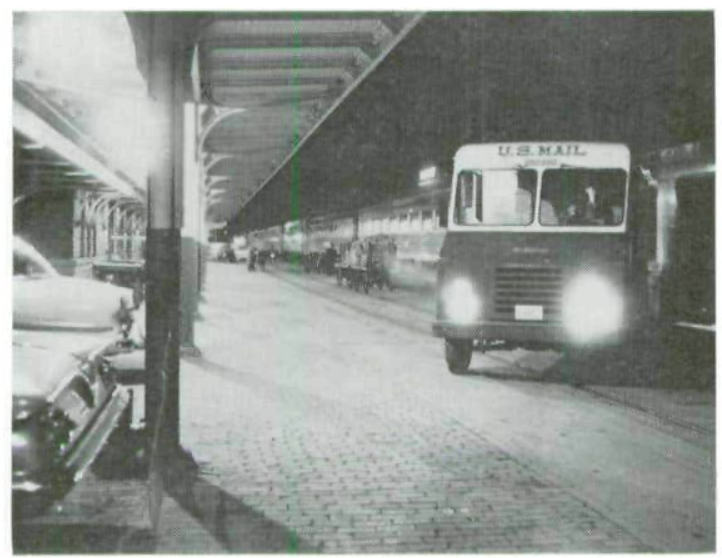

Courtesy of Rock Island Lines

Des Moines Station-Rocky Mt. Rocket, westbound.

Star's run from Minneapolis to Kansas City, substituting a club-diner for its snack beverage car. This step was called a move to "entice the traveling public to use this train when traveling between the points it operated." ${ }^{174}$ Also, since the train no longer traveled to the Lone Star State, the Rock Island felt the need to change its name, which it did in 1966, to the Plainsman.

Plainsman? What an unexciting name compared to the Twin Star Rocket. As mentioned, the road had already dropped the Rocket reference from trains 7 and 8 , the former Rocky Mountain Rockets. At the time, the Rock Island did not really admit to an intentional dropping of the Rocket name. "We are not necessarily attempting to drop the reference of Rocket from our passenger trains as we do have four trains remaining which bear this reference. Those trains from which this reference has been removed were renamed in accordance with the physical area through which they are operated." 175 Yet, the trains were still referred to as the Rockets by the public so they could just as well have been called "Rockets." Even the depot agents this writer interviewed referred to the last trains as the Rockets, which of course they

${ }^{174}$ Bonesteel, letter, 21 December 1966.

${ }^{175}$ Bonesteel, letter, 21 December 1966. 
weren't. But, the Rock Island management perhaps didn't feel the trains could any longer uphold the image of the once famous Rockets. Also, the Rockets, for the most part, were a distinct group, having been put into service between 1937 and 1947.

Murl H. Bonesteel became head of passenger services on the Rock Island in $1966 .{ }^{176}$ Whether this appointment had anything to do with the dropping of the name Rockets is only speculatory, but certainly this could have been part of it. Also it is hard to say whether Bonesteel's appointment to the head of the passenger department had anything to do with the change in Rock Island service, yet the facts show that definite changes in service were made in 1966; he had been manager of the Dining and Sleeping car services when these cars were taken off in $1965 .{ }^{177}$ Thus, Bonesteel's name could be associated with loss of equipment.

In November 1966, the Rock Island announced it was asking to discontinue its last passenger trains between the Twin Cities and St. Louis, effective December 8. The reason for the discontinuance was described as "one combination reason: Public disinterest-lack of patronage, that is-and a $\$ 210,000$ annual out of pocket loss." ${ }^{178}$ Congressman Schmidhauser of the First District of Iowa didn't particularly like the plan. He claimed the passenger trains were important "to keep the economy of the 1st District of Iowa healthy and growing." ${ }^{179}$ Yet, the fact is that Congress had done very little to help the passenger train at that time. But, the ICC investigated the proposal, so the trains were not taken off in December, but rather were kept running until April 1967, at which time the ICC gave its blessing to take the trains from service. There is question as to just how important the trains were. For example, at an ICC hearing at Cedar Rapids in January 1967 , local city officials failed to raise any protest concerning the end of passenger services. After investigation, the ICC ruled that adequate service was prcvided by other rail, air

${ }^{176}$ RI Timetable, 30 October 1966, p. 11.

${ }^{177}$ Rock Island passenger Timetables, 25 April 1965, p. 11.

${ }^{178}$ Des Moines Register, 2 November 1966.

${ }^{179}$ Des Moines Register, 1 December 1966. 
and highway transportation. ${ }^{180}$ The other rail service mentioned here was for passengers bound from St. Louis to the Twin Cities to transfer in Chicago. This trip took no longer than the CB\&Q-RI trip, including the transfer. ${ }^{181}$ Thus, the former Zephyr Rocket was not on a very fast schedule. On the last run, only four people boarded the train at Cedar Rapids, a city of 100,000 people. It was stated that this was about an average number of passengers for this city. ${ }^{182}$

In 1966, the Rock Island was still making the plea that it liked passengers, and perhaps it did. The passenger traffic management made the following statement, "Please be assured that we do appreciate passenger traffic and make every effort within our means to provide a service which will be acceptable to the traveling public." " 183 Also, the personnel were helpful, at least in some cases. "If we may be of any further help to you please feel free to contact us." ${ }^{184}$ This is certainly not a statement some people would expect. There simply are courteous rail personnel around, and too often, it seems, the public has overlooked this.

The discontinuance of the former Zephyr Rockets in early 1967 was only the first step in the tragedy that hit the Rock Island's passenger trains in 1967. In March 1967, the announcement was made that the Post Office was making a study of the merits of the railway post office car service compared to alternate service which could be provided by trucks or planes. Jervis Langdon, upon hearing this, sent a letter to business leaders along the Rock Island mainlines saying he hoped the communities would support retention of the railway post office cars on the Rock Island passenger trains. ${ }^{185}$ Again, there is question in this writer's mind as to just how much the public did do to support Mr. Langdon's plea. No evidence of any support could be found. Certainly if there was support it was not very well publicized.

${ }^{180}$ Des Moines Register, 31 March 1967.

${ }^{181}$ Official Guide, XCIX (November 1966), p. 226, 658, 597.

${ }^{182}$ Des Moines Register, 10 April 1967.

${ }^{183}$ Bonesteel, letter, 21 December 1966.

${ }^{184} \mathrm{~F}$. M. Brown, Rock Island Depot Ticket Agent, Des Moines, letter, 22 April 1966, to the author.

${ }^{185}$ Des Moines Register, 23 March 1967. 
Several Railroad Post Office cars were removed from Rock Island trains, effective May 1, 1967. Jervis Langdon said the Rock Island would lose $\$ 1,000,000$ annually because of this action. He stated that the financial structure of the railroad was such that it could no longer operate deficit-producing passenger trains. ${ }^{186}$ The Post Office claimed the moves were being made to increase efficiency and eliminate a costly service that "was becoming unnecessary." Post Office officials said the RPO's were more expensive than planes or trucks. ${ }^{187}$ Because of this action officials of Rock Island said that four passenger trains would be discontinued May 1, 1967. ${ }^{188}$ The only passenger trains on the Rocky Mountain Route that remained after this action were train 7 , no longer called the Cornhusker, and train 10, no longer called the Corn Belt Rocket. Also, the schedules of these trains were adjusted, with \#10 taking 25 minutes longer for its run than before. ${ }^{189}$ Evidently train \#10 was having difficulty making it to Chicago on time, and thus the schedule was lengthened. Yet, this longer schedule would certainly not help to encourage passengers to use the train.

Jervis Langdon was continually keeping the public alert to the fact that more trains might have to be abandoned unless the public would make an effort to do something about it. He said, "Even with the adjustments started May 1, our passenger business is a marginal business and public patronage of these trains is necessary for their continued operation." ${ }^{190}$ Langdon also pleaded that the railroad would continue to operate trains that the public would support. ${ }^{191}$

Even though the Peoria Rockets were not taken off in 1967, the RPO's from trains 11 and 14 were pulled off. These RPO's, however, only accounted for $\$ 60,000$ annual revenue ${ }^{192}$ as compared to the $\$ 355,000$ the Cornhusker would lose as a

${ }^{186}$ Des Moines Register, 1 May 1967.

${ }^{187}$ Des Moines Register, 29 October 1967, p. 1-L.

${ }^{188}$ Des Moines Register, 1 May 1967.

${ }^{189}$ Rock Island timetable, 1 May 1967; October 1966. $1967)$

190"Passenger Train Adjustments," The Rocket XXVI (May-June,

${ }^{191}$ Des Moines Register, 23 March 1967.

192"Petition Commissioners to End Train Runs," The Rocket, XXVI (November-December, 1967), 15. 
result of the dropping of the RPO's from it. ${ }^{193}$ Similar to what the Rock Island had done a year earlier with the Plainsman, Club-diners were placed on the Peoria Rockets in place of the Snack Beverage cars. M. H. Bonesteel gave the following reasons for the upgrading of service; "The Rock Island has been continually studying its passenger train service between Peoria and Chicago in an effort to tailor the service to what the people of Peoria want. While we cannot afford to to buy new equipment, we have and will continue to emphasize cleanliness and safety on the train. Club-Diner menus and prices have been very popular on the Plainsman and the Golden State." ${ }^{\prime 94}$ There has been some speculation that railroads put luxury equipment of this type on trains it was about ready to take off in order to get the expenses up, and thus make the trains even heavier money losers. While this might have been the case at times, it appears that Rock Island was trying to offer the best service they felt they could afford. Even when two Peoria trains were taken off in 1969, the other trains retained the club-diners, which are still running today.

In the end of May 1967, the Rock Island announced its proposal to discontinue trains $15 \& 16$ between Kansas City and Minneapolis. ${ }^{195}$ These had been nameless trains since 1963 when the name Kansas City Rocket was dropped. ${ }^{196}$ The trains were principally mail and express trains carrying one passenger coach. This writer rode train 16 from Nevada, Iowa to St. Paul shortly before it was discontinued, and found the ride quite rough. The train was late and was trying to make up time. Everytime there was a curve in the track, there was a jerk in the whole car. Either the springs were bad, or there was something wrong with the coupling between the cars, or the roadbed was in poor shape. Also, a lack of any food service was missed. The personnel were courteous, however, and the coach was quite clean. The only coach on the train was not much more than half full, however, so it is no wonder that the Rock Island announced that it suffered losses of $\$ 431,533$ on the

${ }^{193}$ Des Moines Register, 23 March 1967.

194"Club-Diners Replace Snack Cars on Peoria Trains," The Rocket, XXVI (January-February 1967), 15.

${ }^{195}$ Des Moines Register, 26 May 1967.

${ }^{196}$ Official Guide, April 1963, p. 682. 
trains in 1966. Said M. H. Bonesteel, "The Rock Island isn't able to absorb such losses on its passenger train services." ${ }^{197}$ Few would be able to argue that point. Even if they were able, there is little reason why the trains should have to have continued. Even if the trains were termed a public necessity, which they weren't, there is no reason why a private company should have to absorb such losses. If the ICC felt they should be run, they should have paid for the losses themselves. The Rock Island was given permission to discontinue the trains effective October $30,1967 .{ }^{198}$

Also in 1967, Rock Island asked for and was granted permission to drop trains 21 and 22 , the last trains running between Memphis and Tucumcari, which had made connections for California. Said the Rock Island, "the primary function of these trains was to handle mail and express." One passenger coach was more than enough to take care of riders. In 1967, the Post Office removed not only the RPO's on these trains, but also the California bound bulk mail. These reductions removed about $\$ 1.2$ million worth of annual business, making them drastic money losers." ${ }^{199}$ Granted, these trains were primarily mail and express trains, with a passenger coach hooked on, yet, there did seem to be some need for these trains, as they were the last trains to connect Memphis, Little Rock, Oklahoma City and Amarillo, all urban centers. Yet, the ICC allowed discontinuance of these trains without investigation. ${ }^{200}$ It does not seem to this writer, either, that the Rock Island tried to do much to encourage passengers to use this train, running it coach only since 1959 , and not giving it any name since that time. It seemed to be a train "left out in the cold" by the Rock Island. As far as this writer is concerned, this train was probably the most neglected passenger train on the Rock Island's mainlines. Permission was given to drop these trains effective November 10, 1967...101

But Rock Island was still experimenting with innovations which would attract more passengers. For one thing, they were

\footnotetext{
${ }^{197}$ Des Moines Register, 26 May 1967.

198“"Pettion Commissioners," p. 15.

199"Petition Commissioners," p. 15.

${ }^{200}$ Wylder, letter, 18 January 1971.

201"Petition Commissioners," p. 15.
} 
still publicizing their passenger tours for groups; they offered many passenger tours even in the later years in an effort to obtain more revenues, and to get people accustomed to riding trains. Rock Island offered tours to Davenport and the Amana colonies as late as $1967 .{ }^{202}$ Also in 1967, Rock Island made a major improvement by remodeling the Des Moines station. It was painted and air-conditioned, with a modernized ticket counter and self service food machines installed. Also, baggage handling was simplified. ${ }^{203}$ The plans for these improvements evidently were made before the Post Office decided to remove RPO's, which also meant the loss of six trains using the Des Moines station in the year of 1967. By the end of the year only four trains were using the station.

Thus, 1967 was a bad year for the passenger trains on the Rock Island. The loss of the RPO cars was not the sole cause for the abandonment of these trains, however. Passenger usage of the trains had dropped off, in part because of declining service. One person said in regard to the Golden State, "The service on the trains has deteriorated, trains were late, and were not kept clean." ${ }^{204}$ The public simply was not happy about the decline in service. As the railroad began to get deeper into debt there was less and less it could do. At times, when something went wrong with a passenger car, the rail. road simply shoved it off to the side. Thus, the availability of equipment went down, too, and along with this, the deterioration of service. ${ }^{205}$ Yet, the railroad could not really be blamed. Their existence depended on making money, and passenger trains were one basic reason why they were not making money on the system as a whole. In fact, in 1966, the Rock Island system operated at a $\$ 3.6$ million loss. ${ }^{206}$ They simply had to cut out runs that were not making money. The actual facts concerning the drop of passenger service stand like this; as late as 1964, 35\% of Rock Island's train

202"Popular Summer Passenger Tours Offered Again," The Rocket, XXVI (July-August, 1967), 14.

${ }^{203}$ "Refurbish Des Moines Station," The Rocket, XXVI (SeptemberOctober, 1967), 11.

${ }^{204}$ Des Moines Register, 30 November 1967.

${ }^{205}$ James Windsor, 8 January 1971.

${ }^{206}$ Des Moines Register, 20 September 1967. 
miles were in passenger service, while by 1966, this had dropped to $26 \%$, and in 1967 , only $8 \%{ }^{207}$

The major casualty of 1968 was the end of the Golden State. In its petition, the Rock Island called itself "a carrier which has had a long and serious financial decline in the operation of its system lines since emerging from bankruptcy in 1948." The Des Moines Register described the Golden State as, "once among the most popular streamliners between Chicago and Los Angeles." The Rock Island said it lost $\$ 576,604$ on the Golden State in 1966. It continued by noting a continuing drop in passengers using the Golden State. The daily average dropped from about 374 for both trains in 1965 to 297 in $1966 .{ }^{208}$ The Rock Island said that in addition to the $\$ 576,000$ loss on the trains in 1966 , the loss would be increased by $\$ 302,000$ when the RPO's were dropped from the trains, effective August $12 .^{209}$

The Golden State, once called "Rock Island's premier train," made its final run on February 21, 1968. ${ }^{210}$ The last Eastbound Golden State pulled into La Salle St. Station, Chicago, "in the grand old railroad tradition - on time to the minute." Only 51 passengers unboarded the train that day, and only a very few had come all the way from California. There was some dispute over the dropping of the Golden State, especially in southern Iowa, where some towns would be left without any type of public transportation. The ICC, however, in allowing the discontinuance of the Golden State, "relied heavily" on the Rock Island's financial condition. The ICC acknowledged that although passenger use of the Golden State had dropped, the trains were still used by a number of persons. But the ICC, looking at the Rock Island's financial condition, said the continued operation of the Golden State would make for an "unallyed" drain on its remaining revenues. "The ultimate and overriding factor here, however, is necessarily the Rock Island's inability to sustain the losses involved

${ }^{207}$ Jervis Langdon, jr., "To the Rock Island Stockholders," Rock Island Lines Annual Report, 1967, p. 5.

${ }^{208}$ Des Moines Register, 20 September 1967.

209"Petition Commissioners," p. 15.

${ }^{210}$ Des Moines Register, 20 February 1968. 
in providing service." ${ }^{211}$ Those are the facts. Many people did not understand why the trains shouldn't continue. But yet why should they? The Rock Island simply could not afford the losses incurred by operating the trains. Also, there did not seem to be a great deal of interest at some points. For example, in Davenport, only two public witnesses protested the abandonment. ${ }^{212}$

Another reason the Golden State had financial difficulties was because it had strong competition on its Chicago to Los Angeles run, from both the Union Pacific and Santa Fe. Both these railroads had trains with dome cars, luxurious lounges, and other equipment that the Rock Island was not in the position to purchase. The Golden State had at one time been comparable to these trains, but in recent years had not been able to keep up with the trains of the wealthy Union Pacific and Santa Fe lines. This is backed up by the statement of one train traveler. "If the Golden State was still running," she said, "I would probably still take a Santa Fe train partly because of the more modern equipment on the Santa Fe."213

Even in 1967, the Rock Island claimed they would support trains that wouldn't lose money or that would be supported by the public. Said Jervis Langdon regarding 1967, "the railroad continued to suffer heavy losses on passenger runs despite improved on-time performance, and the assignment of the most modern equipment in our possession." ${ }^{214}$ The railroad also claimed that they had tried their best to keep the Golden State running as long as possible. They had attempted to attract more passengers with reduced family plan fares, more economical food service and other promotional efforts. "Yet the public deserted the Golden State, as it did other passenger trains, to climb aboard the airplanes for long distance travel and the automobile for shorter hauls." ${ }^{215}$

211"Golden State Makes Final Run," The Rocket, XXVII (MarchApril, 1968), 13.

${ }^{212}$ Des Moines Register, 20 February 1968.

${ }^{213}$ Miss Angeline Jacobson, Luther College Reference Librarian, personal interview, 30 November 1970 , with the author.

${ }^{214}$ Des Moines Register, 20 September 1968.

215"Golden State Makes Final Run,” p. 12. 
This is a continuation of the question of who deserted who first. The Rock Island said the public "in effect deserted the Golden State as it has other passenger trains. It is not a case, as so often is said, of the railroad deserting the public." ${ }^{216}$ It seems that the problem was caused by both sides. The Rock Island, however, would not admit that declining use of its passenger trains might have occured because of downgrading of service. Perhaps if they would have admitted to this, a little more understanding among the public would have occured. While they may not have dropped equipment to discourage passengers, it certainly had some effect on some passengers. One employee noted, "after they took the diners off, it didn't seem like anybody was riding the trains any longer." 217 M. H. Bonesteel still insisted "Rock Island will continue to promote passenger service to those communities that support its trains. We cannot continue to run passenger trains which are not used. Although the load factor on the evening train (Rock Island to Chicago) is marginal, and should be better, patronage on the morning train from the Quad Cities is far lower than we had anticipated. We are hopeful that the introduction of the former Golden State cars will induce the public to use the Rock Island more frequently, to and from Chicago." ${ }^{218}$ The Rock Island had not given up. Bonesteel also commented in 1968, "we are cutting fares in an effort to boost patronage. By offering an economy price, we hope to induce more individuals and families to enjoy the convenience of rail travel while making a trip to Chicago. Savings up to $17 \%$ are available and there are also special reduced fares for children." ${ }^{219}$ This writer is convinced that these claims for fare reduction were the actual ones. Some writers have theorized that railroads dropped fares and increased equipment in order to try to get their gross revnue down, shortly before taking trains off. However, the two trains that had fares reduced in 1968 were the Chi-

${ }^{216}$ Des Moines Register, 20 February 1968.

${ }^{217}$ D. D. Dodd, Section Foreman on the Rock Island, personal interview, 14 January 1971, McCallsburg, Iowa with the author.

218"Quad Cities Trains get 'State' cars," The Rocket, XXVII (MarchApril 1968), 14.

${ }_{219}$ "Reduce Certain Passenger Fares," The Rocket, XXVII (MarchApril, 1968), 11. 
cago to Peoria runs and Chicago to Rock Island runs, which are still operating in 1971.

In addition to cutting fares on Chicago to Rock Island runs, the Rock Island replaced the equipment on its Quad Cities trains with more luxurious facilities. This equipment was formerly that of the Golden State's. Three 48-seat chair cars with full leg rests were put on the trains in place of two 68 -seat coaches previously used. The 48 -seat cars were, of course, designed for long distance travel, and thus very comfortable. ${ }^{220}$

Also new on the Rock Island to Chicago trains in 1968 was the famous El Cafe or Fiesta Car, replacing the conventional diner. The Fiesta Car was equipped with handcarved wooden tables and chairs with bright leather. ${ }^{221}$ This car had originally been designed for the Golden Rocket.

Another new car on the Rock Island to Chicago trains in 1968 was a club-lounge. This car was not really run by the Rock Island, rather, it was chartered from the Rock Island and run by Mr. Butterworth of the Butterworth travel agency in Moline. This is quite a story, showing how fine equipment can be made profitable if promoted. The Butterworth clublounge was put into service in late 1967, and gradually became a money-making proposition. Butterworth started the service in late 1967. By mid-1969, his travel agency received 25 percent of its business from train travel, evidence of the success of his venture. The Wall St. Journal said of the success of the Butterworth car, "The Butterworth Line shows there is hope for passenger trains." ${ }^{, 22}$ In early 1971, Butterworth was still finding new ways to encourage train travel. $\mathrm{He}$ has recently purchased a "Vista-Dome" passenger cur, and said, "I bought the car because I believe short-haul passenger service can come back." He feels the airlines no longer want the short-haul passenger, and thus, the highways are becoming increasingly overcrowded. ${ }^{223}$ This development is significant in that it is the first time that a dome car has been run on a regular schedule on Rock Island tracks. Butterworth

220“"Quad Cities Trains," p. 14.

${ }^{221}$ Ibid.

${ }^{222}$ Wall Street Journal, 23 June 1969.

${ }^{223}$ Des Moines Register, 1 February 1971. 
should be commended for his fine contribution to the future of train travel.

There is still more praise for the Chicago to Rock Island trains. In 1968 a couple of news reporters rode the Rock Island trains between Chicago and Rock Island. Both the Moline Dispatch and the Davenport Times-Republican gave favorable reports on the trains. Said the Moline Dispatch:

The new luxurious accomodations and service make the once tiresome trip a joyful experience that more and more Quad Citians are becoming aware of and taking.

Jim Arpy, writer for the Davenport Times-Republican, said,

Let's face it, there's something about riding a train that no other form of transportation can provide. And on this train, every effort is made to make the trip extremely pleasant. You could sum it up like this: 'What a way to go!'?24

These people were not connected with the Rock Island, and were riding the trains to see just how good the service was. This case certainly must have helped the Rock Island's public image and Rock Island should be connected for receiving such high comments.

The Rock Island still had quality in other aspects of their passenger service, too. For example in 1968, for the fourth consecutive year, the Rock Island won a Certificate of Excellence for its Food Services Department, from the U.S. Public Health Service. This award was based on a series of surprise inspections of every club-diner, club-lounge, and snack-beverage car operated by the railroad. ${ }^{225}$

There were some operating problems, too, however. In one case, in July 1968, a Rock Island passenger train carrying 130 passengers to Rock Island arrived there three hours late because the engine ran out of fuel. The report went on to say that the engine was sent to the shops. ${ }^{226}$

Another operating problem was that the roadbed was not in the best condition in some areas. Once in 1968, Mr. Sinclair, a railfan, was riding a Rock Island passenger train that had backed into a siding. He asked the conductor why they had backed in, and the conductor said, "Oh, there's a broken 224"Papers Praise Rock Island Trains," The Rocket, XXVIII (September-October, 1968), 15.

225“"Fourth Dining Award," The Rocket, XXVII (May-June, 1968), 14.

${ }^{226}$ Des Moines Register, 13 July 1968. 
rail at the other end." How often this happened is only speculatory, but it is no wonder passenger trains were late if they had to back into sidings to wait for freights. Also, the roadbed of the Rock Island was not particularily smooth. "Rock Island, along with most roads east of the Missouri, were never known for their smooth rails. The ride on the Union Pacific trains is much smoother in comparison to the Rock Island. ${ }^{{ }^{227}}$

Even though the railroads have often been criticized for their failure to promote passenger service, there have been cases where individuals have done so. Earlier it was mentioned that a travel agent in Moline had begun promoting passenger service. In 1969, Bradley University students began a promotion in support of the Peoria Rockets. In their student newspaper they printed news stories and editorials to help promote these trains. Said the newspaper, "Peoria citizens and we, as Bradley students and citizens of Peoria, must continue to use whatever service is still available. The Rock Island has significantly improved the convenience and comfort of travel by rail and makes passage from Peoria to Chicago and points east and west an easy process." They went on to say, "With the arrival of cold weather and its icy roads, Bradley students are looking for more convenient ways of getting home for weekends and vacations, and the Rock Island is the means of doing that." Bradley students responded to these editorials, and for students returning from Christmas vacation in 1969, the Rock Island ran a special train for them from Chicago to Peoria, and over 250 students used that special train. ${ }^{228}$

The announcement that had been anticipated for some time came in July 1969 when the Rock Island asked for permission to discontinue trains $17 \& 18$, the Plainsman. These were the remnants of the once famous, Twin Star Rocket. The Rock Island said the two trains operated at a $\$ 1.2$ million loss in $1968 .{ }^{229}$ These two trains were once well-known and patronized throughout central Iowa. The number of passengers riding on them had dropped off sharply in recent years, however.

${ }^{227}$ Luke Snclair, railfan, personal interview with the author at Mr. Sinclair's home, Ames, Iowa, 23 October 1970.

228"Peoria Passenger Service Promoted," The Rocket, XXIX (January-February, 1969), 15.

${ }^{229}$ Des Moines Register, 23 June 1969. 
One person mentioned, "There was hardly anybody riding the trains before they were taken off. People just didn't use them. Many of those who were riding were non-paying passengers, mainly employees and retired employees."230 The ICC decided not to conduct hearings regarding the proposed discontinuance of 17 and 18, and the trains ended their runs in July $1969 .{ }^{231}$

The Club diners that had been operating on 17 and 18 were switched over to trains 7 and 10 operating between Chicago and Omaha. These trains had previously had a snack beverage car, but no diner. The Club diners included an attractive lounge area where beverages were served. The snack beverage cars they replaced offered a much more limited menu. ${ }^{232}$

A major change in terms of nostalgia was the change in the names of the Peoria Rockets in 1969. The trains became simply the Peorian ${ }^{233}$ and Rock Island was no longer "Route of the Rockets." For the most part, however, Rock Island had not been the route of the same Rockets in the late 60 's as they had been in the 40's and 50's. The Rockets had lost their eliteness, including parlor cars and sleepers. Also, they often had freight cars in their consist in the late 60's. Evidently the Rock Island had run short of streamlined express cars for hauling storage mail and had gone to using box cars. This certainly was not a typical Rocket image, so perhaps the Rock Island was justified in dropping the name "Rockets" from their trains when they did.

In early 1970, Rock Island began terminating trains 7 \& 10 at Council Bluffs instead of Omaha. The Rock Island said the move was an economy measure and would save the railroad $\$ 200,000$ annually. ${ }^{234}$ Passengers who were traveling to Omaha would have to find their own way of getting there. The motive for dropping this service seems quite obvious to this writer - it was a way to discourage passengers. Who would ride a train from Chicago ending at Council Bluffs when two other railroads offered service into Omaha? Also,

${ }^{230}$ G. J. French, Rock Island Depot Agent, Nevada, Iowa, personal interview with the author, 14 January 1971.

${ }^{231}$ Des Moines Register, 24 July 1969.

${ }^{232 " C l u b}$ Diners Replace Snack Beverage Cars," The Rocket, XXIX (September-October, 1969), 15.

${ }^{233}$ Rock Island Passenger timetables, 2 March 1969.

${ }^{234}$ Des Moines Register, 6 January 1970. 
Omaha is about five times larger than Council Bluffs and it seems ridiculous to have ended the trains at Council Bluffs. Jim Windsor called the move, "The beginning of the end." ${ }^{235}$

The end he is referring to here is, of course, the end of Rock Island passenger trains in Iowa when 7 and 10 were discontinued on May 31, 1970. The ICC, in a very unusual case, permitted discontinuance of the trains while still investigating the need. There were some definite reasons why the Rock Island wanted to discontinue these trains. Jervis Langdon said the road was losing $\$ 1.3$ million a year on the trains. ${ }^{236}$ The Rock Island said it would require 466 passengers a day to break even, and the trains averaged only 126 a day. ${ }^{237}$ From these figures they determined they would need a subsidy of $\$ 10$ a passenger to operate the trains. ${ }^{238}$

The trains received a great amount of publicity on their last runs. Train \#10 was not brought into the Council Bluffs station until 11 a.m., though it was due to leave at 10:40. "Just late getting around to it," explained the switch foreman. ${ }^{239}$ This does not seem like much of a way to run a railroad. The last trains were equipped with three passenger cars, one dining car, one baggage car and two locomotives. ${ }^{240}$ The Rock Island did not feel responsible for having to drop the trains. They said, "The Rock Island had equipped the trains with comfortable stainless steel air-conditioned coaches and an attractive diner, which served budget priced meals." They went on to explain that the trains were costly to operate; while the average revenue was $\$ 735$ per day for the two trains, crew costs alone were $\$ 1,240$ per day. These crew costs should not have been that high, but there was nothing the Rock Island could do about it. ${ }^{241}$

There had been a noticeable drop in the service provided by trains $7 \& 10$ in addition to the new Council Bluffs termination. In early 1970, the Rock Island had filed a petition to

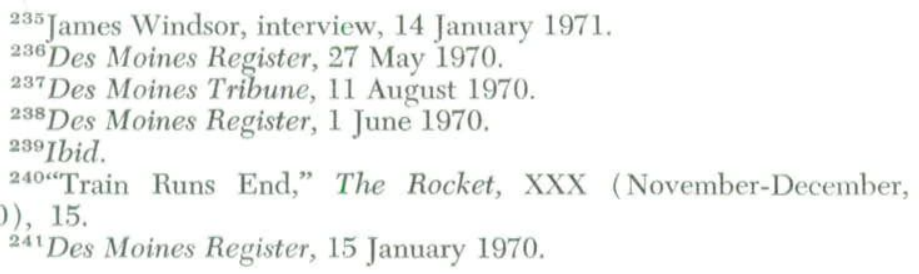


end baggage service on these trains which would mean all passengers would have to carry their own bags. ${ }^{242}$ Also, the trains ran on a schedule that was considerably slower than in the 50 's.

The number of people using the trains had dropped considerably. Said one engineer, "The most passengers we'd have would be about 18, in the last year. On a normal day, even ten years ago, we'd haul 450-500 passengers." ${ }^{243}$ To further back this up, the conductor on the last run of train 10 said, "Some days I don't handle a dozen people all the way across Iowa." On the last train run, however, 365 tickets were collected across Iowa, largely from those taking last rides. ${ }^{244}$ Also, there were 400 people in Des Moines to watch the last Eastbound Rock Island train come in. ${ }^{245}$

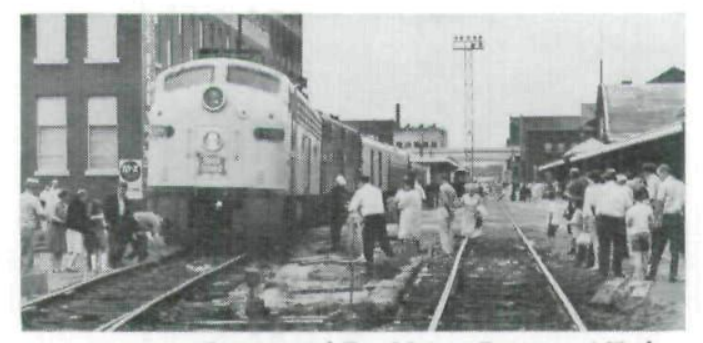

Courtesy of Des Moines Register हु Tribune

\section{Eastbound Train No. 10 at Des Moines Station,} June 1, 1970.

Grinnell students had done what they could in trying to keep the trains running. About 200 Grinnell College students protested the proposal of discontinuance; ${ }^{246}$ they had used the trains. Agent E. R. Carlson in Grinnell said that when school let out for vacations, he would call in and ask that an extra car or two be added to the passenger trains. ${ }^{247}$

Many people other than the Grinnell students did what they could to keep the trains running. State officials referred to the poor on-time record of the trains; from May 1969 to June 1970, the train in Des Moines arrived on time only once

${ }^{242}$ Des Moines Register 15 January 1970.

${ }^{243}$ Des Moines Register, 31 May 1970.

${ }^{244}$ Des Moines Tribune, 1 June 1970.

${ }^{245}$ Des Moines Register, 1 June 1970.

${ }^{246}$ Des Moines Tribune, 29 April 1970.

${ }^{247}$ E. R. Carlson, interview, 11 January 1970. 
and departed Des Moines late every single day of the year. In addition, train 7 arrived in Omaha on time only six times during the entire year. ${ }^{248}$ There is little question that this problem helped to discourage passengers.

The Iowa Commerce Commission was very disgusted with the Rock Island and the ICC. They didn't feel the trains should have been dropped. They said of these trains and the Rock Island:

There is nothing reasonable about this carrier's outrageous performance, and it should not be permitted to benefit from its failure to provide reasonable service. The Rock Island did little or nothing to encourage the public to ride its trains and that, in fact, passengers were deliberately and systematically driven off . . . The passenger trains were operated in a manner reminiscent of the Toonerville Trolley. ${ }^{249}$

Some of what the commission says here may be true. Yet they have gone to extremes in stating their case. For one thing, they give no evidence to back up the fact that passengers were deliberately and systematically driven off. Also, they make no mention of the many things the Rock Island tried in order to attract passengers. Finally, they put the blame on the Rock Island solely, giving no hint that the public might have decided it would rather use other means of travel. The unfortunate thing here is that the Iowa Commerce Commission did not seem to realize the real problem involved. They had done and said little or nothing prior to this; they could have issued encouragements to the public to use the trains. Also, it is questionable whether they had contacted Rock Island when they began to feel the railroad no longer provided, as they say, "reasonable service."

The Iowa Commerce Commission was so disgusted with the Rock Island that they tried to get a court order to keep the trains running. They felt it would be useless to hold hearings after the trains had been discontinued. ${ }^{250}$ Here they had a point. It was a strange situation when the ICC ordered an investigation yet permitted the trains to be dropped. On October 1, 1970, the ICC said the trains could end permanently. ${ }^{251}$

\footnotetext{
${ }^{248}$ Des Moines Tribune, 11 August 1970.

${ }^{249}$ Ibid.

${ }^{250}$ Des Moines Register, 2 June 1970.

251“"Train Runs End," p. 15.
} 
Again, the question arises as to just how much the Rock Island tried to encourage passengers. According to the ICC they did absolutely nothing. Mr. L. Sinclair also thought they had made little effort to keep the trains going and mentioned it to an old retired employee of the Rock Island, as they both watched the last Rock Island passenger train in Iowa last May. The retired employee said, however, "yes, we tried. We tried everything, but the patronage just steadily declined." ${ }^{252}$ Another railfan felt factors of train speed, scheduling, quality of service and on-time performance were all aspects of the Rock Island service in need of improvement. ${ }^{253}$ This again points to the problem of just whom should one believe? The public or the railroad? This writer thinks both are to blame, but the railroad less so as the facts are studied. For the most part, the public has little to back up its statements that the railroad discouraged passengers before passengers began seeking other means of travel. It is true that in the late 60 's, the railroad discouraged passengers by offering a deteriorating service, but wasn't this after the public had already left the rails? The way one college student puts it makes a lot of sense:

The State of Iowa did nothing to try to get people to ride these trains $(7 \& 10)$ or make them profitable operations. Now that Des Moines and most of Iowa are without passenger service, we should not complain. We had it. We did not use it. So, now we will do without it..$^{254}$

Jervis Langdon resigned at the end of July 1970 as chairman and vice president to become a trustee for the Penn-Central. On September 14, 1970, three top men were elected to Rock Island positions. Peter Kiewit was elected to acting chairman of the board, Theodore E. Desch was elected vice chairman of board, chief executive and a director, and William J. Dixon was elected as president. ${ }^{255}$ It is still hard to say whether these changes will have any affect on passenger service.

In 1971, the Rock Island still has passenger trains running between Chicago and Rock Island and between Chicago and Peoria. Both trains still have a club diner, club parlor and chair cars in their consist.

${ }^{252}$ Luke Sinclair, 23 October 1970.

${ }^{253}$ Stephen Wylder, railfan, letter 4 May 1970 to ICC.

${ }^{254}$ Des Moines Register, 6 December 1970.

255"Board Meets," The Rocket, XXX (September-October, 1970), 2. 
It has been seen how the Rock Island passenger train drastically went down-hill in the 60 's. Perhaps the death of Farrington in 1961 had something to do with this decline, and certainly the securing of Jervis Langdon as president had something to do with it, also. Langdon was to get the Rock Island back on its feet, financially, and thus he could do little but cut losses in the passenger department. Langdon didn't seem to hate passenger trains, he just hated deficit, as any good president should. Nineteen sixty-five, of course, was the big year for change in Rock Island's passenger service when all diners, parlor cars and sleeping cars were dropped from all trains save the Golden State. Nineteen sixty-seven was the year when so many trains were dropped, largely because of the Post Office decision to remove RPO's from most trains. The Rock Island's famed Golden State, operating since 1902, was dropped in early 1968. The last trains to run on the Mid-Continent route were dropped in 1969. And finally, the last remaining segments of the Rocky Mountain Rocket and the Corn Belt Rocket were dropped in 1970.

The question of who deserted first, the railroad or the public, is a question that came up almost everytime the railroad asked to take a train off. Because this question has been such a heated one in the past few years, it will be gone into a little more deeply in the next section in order to determine as much as possible, "who deserted first?"

PROBLEMS OF PASSENGER TRAINS

In this section we shall look at the problems railroads have in operating passenger trains. Rock Island's problems are similar, of course, to most railroads.

There is the question of just how much chance the railroads had of making a success out of passenger business after the airlines began fighting for business. As early as 1950, the airlines were telling the railroads to relinquish the fight for passenger service. The president of one of the leading airlines told the railroads in the October 3, 1949 issue of Life, "Get out of the passenger business for all trips over 200 miles." At that time, one writer, R. Hannon, an airline employee, called this remark an entirely hypothetical statement. ${ }^{256}$ We have seen, how-

${ }^{256}$ Raymond Hannon, "Why Airlines are Winning the Passenger Battle," Railroad Magazine, LII (July 1950), 12. 
ever, that it looks as though most railroads, including the Rock Island, have taken the advice of that airline president. The Rock Island's longest passenger train run is now 181 miles. ${ }^{257}$ Hannon felt that as early as 1950 , there was little question as to why the railroads did not have the passenger traffic that they had the potential of securing. "The rudeness of railroad employees is now legendary. The strain of discourtesy is almost indelibly printed in the public mind. In a million miles of travel I've seen passengers insulted and even sworn at dozens of times." On the other hand, said Hannon, the airlines literally worshipped the passenger, giving them good and fair treatment, both in worth and attitude. He goes on to say that the airlines, in 1950, often misrepresented the railroad's passenger service, calling the railroads slow and even unwilling to rally to the challenge, while the railroads did little about it. ${ }^{258}$ The airlines were just in a better position to attract passengers; this was their livelihood, unlike the railroads where passenger service was not the basis for survival and in fact, in many cases, was a detriment rather than an asset.

One major cause for the railroads' disinterest was, in part, due to their high cost of operating passenger trains in terms of labor. In one example, between Chicago and Denver, 42 percent of train revenue was taken for labor, while 16 percent of plane revenue was spent on labor. ${ }^{259}$ Trains simply have had a hard time of making a go of it because of high labor costs. Engineers and firemen on passenger trains get a full day's pay when their runs go 100 miles. If they go over 100 miles they get overtime pay. This "basic day" rule dates back to 1919 when the average speed of passenger trains was 20 m.p.h. ${ }^{260}$ Thus, the unions are also one of the chief causes for the death of the passenger train.

Even in 1916 it was stated, "there are many reasons why the passenger business of American railroads does not pay."

${ }^{257}$ Official Guide, CII (May 1970), p. 489.

${ }^{258}$ Hannon, "Why Airlines are Winning," p. 18, 20, 25.

${ }^{259}$ Stover, American Railroads, p. 227.

260"The Dying Passenger Train," U. S. News and World Report, XLV (October 3, 1958), 38.

${ }^{261}$ John A. Droege, Passenger Terminals and Trains, 1st edition, (New York: McGraw-Hill Book Co., Inc. 1916), p. 3. 
This statement sounds like it would more likely have come from the decade of the 60 's. In comparison to freight trains, however, passenger trains did not make a lot of money even back in the 1910's. For instance, in 1912, average earnings per passenger train mile were only $\$ 0.975$ while earnings per freight train mile were $\$ 2.486 .{ }^{262}$ The railroads in 1916 realized something would have to be done. "The problem before the American railroads today is to determine how they can best make their passenger traffic lucrative again." ${ }^{263}$ Thus, there were many problems in the early 20th century just as in the 50 's and 60 's.

There are some advantages to operating money-losing passenger trains. "Name trains are revenue earners on most roads, and even where not, their operation contributes handsomely to an important quality called prestige. Fine trains and attractive facilities focus attention on the railroad and bring in freight revenue by influencing shippers, who are also a part of the traveling public." 264

However, just how efficient are passenger trains? George Hilton, professor of Economics at UCLA, said of rail passenger service, "Less flexible than the automobile, more expensive than the bus, slower than the plane, the passenger train has lost all its advantages, save only an excellent safety record." ${ }^{265}$ Thus, just how important is the passenger train? This writer feels it mainly depends on the length of a run. As mentioned, the passenger train will become increasingly more important, especially on runs of 300 miles or less.

The railroads have been blamed for almost everything by some people. They were blamed if they took equipment off. They were blamed if they put equipment on. Some of these claims were probably justified, but certainly not all of them. One writer claimed some railroads "embarked on campaigns to drop trains and frustrate passengers." He also wrote about the various things some railroads had done to make

${ }^{262}$ Poor's, 1914, p. 1123.

${ }^{263}$ Droege, Passenger Terminals and Trains, p. 5.

${ }^{264}$ Hannon, "Why Airlines are Winning," p. 27.

11.

${ }^{265}$ “Stan Freberg meet Professor Hilton," Trains, XXVI (July 1966), 
passenger travel impractical. ${ }^{266}$ However, in some cases, the railroads did make for poor connections, and the like, in order to be able to drop a marginal train. Although it has been mentioned several times, there still is no reason why a private company, such as a railroad, should have to absorb losses on passenger trains. If the ICC wouldn't allow them to drop trains that were causing a financial strain on the company, it does not seem strange that the railroads did certain things to discourage passengers in order to have a better chance of dropping the train. One such example seems to be when the Rock Island changed the western terminus of trains 7 and 10 from Omaha to Council Bluffs.

Another writer had little patience for or understanding of the railroads. He said in reference to Southern Pacific (SP), it "lain awake nights figuring out ways to discourage passengers." He went on to say, "the railroad's steak sandwich is even tougher than the heart of an SP reservation agent," and claimed the carrier "would give its left diesel to trade passengers for cattle and rutabaga." ${ }^{267}$ Even though he is referring to Southern Pacific here, he would probably apply it to Rock Island as well. But the fact still remains, however, that passenger trains have never been very good money makers.

As mentioned throughout this paper, "There is violent argument over whose fault this is." ${ }^{, 288}$ An ICC report in 1958 showed that at that time, the railroads had indeed tried to improve equipment and service and thus tried to turn a profit on passengers. The ICC said the railroads invested more than a billion dollars between 1946 and 1965 on new equipment. ${ }^{269}$ This, of course, is what the railroads have said. They claim the general public abandoned the passenger train long before the railroads discontinued any significant number of them. ${ }^{270}$ In addition they claim that "nothing the Railroads have tried has helped in solving the passenger problem." This was backed

${ }^{266}$ Wright, William R., "The Nuisance of Passengers," The Nation, CCIV (February 27, 1967), 276.

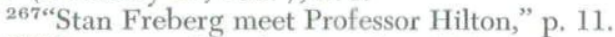

268"Fewer-and far between," p. 117.

269"The Dying Passenger Train," U. S. News and World Reports, XLV (October 3, 1958), p. 37.

${ }^{270}$ Stover, The American Railroad, p. 196. 
up by the ICC report, too. ${ }^{271}$ Even Santa Fe, noted for its pro-passenger attitude, came to the conclusion, "Santa Fe has not abandoned the traveling public-travelers show an increasing preference to drive or fly." ${ }^{272}$ Even bus lines in cities are having the same problem. When people become affluent, they prefer to drive or fly.

The Rock Island has never admitted that it has given up on passenger trains. It continued to insist that the Rock Island didn't drop passenger services until it became evident the public no longer wanted these services. As late as 1969, the company issued an optimistic statement regarding rail passenger service, "Steps have been taken to make passenger service as attractive as the company's limited financial resources will permit, in the belief that while a train is being run the company wants its patrons and the communities it serves to think well of the Rock Island." ${ }^{273}$

\section{SUMMARY}

We have seen how the Rock Island's passenger trains developed since the beginning of the 20th Century. Also, this development has been compared to that of railroads in general. The Rock Island had some classic trains running in the early part of the 20th Century, including the Golden State Limited and the Rocky Mountain Limited. The largest innovation in regard to Rock Island passenger service was the inauguration of the Rockets beginning in 1937. The Rockets helped to boost the company, both financially and morally. The war years from 1942 to 1945 were years of extremely high usage of passenger trains, and the Rock Island's trains rose to prominence in those years. After the war a few more Rockets were placed in service. By 1950, only branch line passenger business had been cut off. By 1953, there were no steam powered passenger trains left on the Rock Island. In 1956, the Rock Island introduced the Jet Rocket, and this train, of very modern design, was supposed to make passenger business profitable. Unfortunately, there were too many prob-

271"cThe Dying Passenger Train,” p. 36.

${ }^{272}$ David P. Morgan, "Santa Fe Calls it Quits," Trains, XXVIII ( January 1968), 4. p. 11.

${ }^{273}$ Jervis Langdon, jr., "To the Rock Island Stockholders," 1969, 
lems with the Jet Rocket, and it had to be taken off, after only a year and a half of service. In the mid-50's, there seemed to be a slight change in the passenger picture. Even though no mainline, through trains were taken off, certain luxury equipment was being cut, such as the round-end observation car on the Rocky Mountain Rocket. As far as the Rock Island is concerned, 1960 seems to be a major turning point in its passenger service. In 1960 the Rock Island took off one of its Des Moines Rockets. This train was a favorite of many and these people did not appreciate having this train dropped. In the beginning of 1964, all mainline trains were running that had been running in 1961. By the end of 1965, however, several trains had been dropped including 17 and 18 between Fort Worth and Houston, 39 and 40 between Kansas City and Rock Island and 23 and 24 between Memphis and Amarillo. In 1965 all sleeping cars, lounges and diners were taken off, except for the Golden State's. In 1966, two long running trains were dropped. Nineteen sixty-seven was a very bad year for passenger trains on the Rock Island when the RPO cars were taken off several trains, and these trains were then discontinued. By June 1970, the only Rock Island passenger trains still running were those between Chicago and Peoria, and between Chicago and Rock Island.

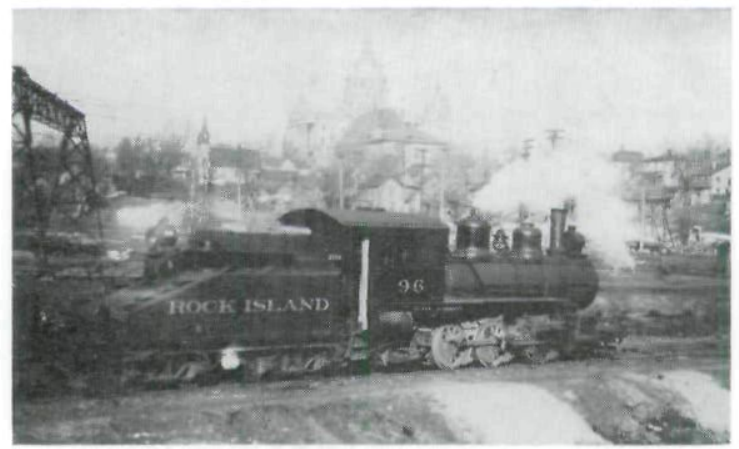

Courtesy of Des Moines Register 8 Tribune

Old 96-Rock Island locomotive on tracks below the Statehouse. This photograph was taken in 1913. Compare Old 96 to the ultra-Streamlined Rocket, p. 730. Note the change in engine designs. 


\section{BIBLIOGRAPHY}

Beebe, Lucius and Charles Clegg, The Trains We Rode, Vol. II. Berkeley, Calif.: Howell-North Books, 1966.

Dubin, Arthur D., Some Classic Trains. Milwaukee: Kalmbach Publishing Co., 1964), p. 221.

Droege, John A., Passenger Terminals and Trains, 1st edition. New York: McGraw-Hill Book Company, Inc. 1916.

Farrington, S. Kip, jr., Railroads of Today. New York: Coward-McCann, Inc., 1949.

Hayes, William Edward, Iron Road to Empire. New York: SimmonsBoardman Publishing Corp., 1953.

Stover, John F., The Life and Decline of the American Railroad. New

Books: York: Oxford University Press, 1970.

\section{Company material-CRI\&P RR:}

Farrington, J. D., "To the Stockholders: CRI \& P RR Co.," Annual Report to the Stockholders, 1953, p. 4-10.

Farrington, J. D. "To the Stockholders: CRI \& P RR Co.," Annual Report to the Stockholders, 1954, p. 4-11.

Farrington, J. D., "To the Stockholders: CRI \& P RR Co., Annual Report to the Stockholders, 1955, p. 4-11.

Jenks, D. B., "To the Stockholders," Rock Island Annual Report to the Stockholders, 1958, p. 4-11.

Jenks, D. B., "To the Stockholders," Rock Island Annual Report to the Stockholders, 1959, p. 4-11.

Johnson, R. E., "To the Stockholders," Rock Island Lines Annual Report, 1962, p. 4-11.

Langdon, Jervis, jr., "Statement in relation to proposed Discontinuance," ICC Finance Docket \#26175, p. 1-9.

Langdon, Jervis, jr., "To the Rock Island Stockholders," Rock Island Lines Annual Report, 1964, p. 4-9.

Langdon, Jervis, jr., "To Rock Island Stockholders," Rock Island Lines Annual Report, 1967, p. 4-13.

Langdon, Jervis, jr., "To the Rock Island Stockholders," Rock Island Lines Annual Report, 1969, p. 4-13.

\section{Public Timetables:}

21 March 1909.

12 March 1922.

29 September 1929.

25 July 1937.

22 November 1942.

July 1952.

27 April 1958-Condensed.

25 October 1959.

30 April 1961.

29 April 1962.

25 October 1964.

25 April 1965.

31 October 1965.

24 April 1966.

30 October 1966.

1 May 1967.

5 November 1967. 
14 July 1968.

2 March 1969.

1 March 1970.

Rocket magazines listed with serials:

"Traffic Statistics: Passenger Service," Rock Island Annual Report, 1955, p. 22.

"Train, Locomotive and Car Mileage," Rock Island Annual Report to the Stockholders, 1952, p. 21.

"Train, Locomotive and Car Mileage," Rock Island Annual Report to the Stockholders, 1954, p. 21.

Interviews:

Carlson, E. R., Rock Island depot agent, personal interview with the author at the Grinnell Depot, 11 January 1971.

Dodd, D. D., Section foreman on the Rock Island. Personal interview with the author at the McCallsburg depot, 14 January 1971.

French, G. J., Rock Island depot agent. Personal interview with the author at the Nevada, Iowa depot, 14 January 1971.

Jacobson, Angeline, Reference librarian, Luther College. Personal interview with the author at the Luther College Library, 30 November 1970.

Richardson, Leon, retired Rock Island switchman. Personal interview with the author in Des Moines, 19 December 1970.

Sinclair, Luke, railfan. Personal interview with the author at Mr. Sinclair's home, Ames, Iowa, 23 October 1970.

Windsor, James H. III, Rock Island railfan. Telephone interview with the author in Des Moines, 8 January 1971.

Windsor, James H. III, Rock Island railfan. Personal interview with the author at Mr. Windsor's home, Des Moines, 14 January 1971.

\section{Letters:}

Bonesteel, M. H., Director of Rock Island passenger services. Letter to the author, 21 December 1966.

Brown, F. M., Depot Ticket Agent, Des Moines. Letter to the author, 22 April 1966.

Brown, Robert C., Agent-Yardmaster, Burlington-Northern, Creston, Iowa. Letter to the author, 10 January 1971.

Pate, James, Director of Public Relations, Rock Island Lines. Letter 21 January 1971 to the author.

Smith, Neal, member of congress, 5th District, Iowa. Letter to the author, 13 May 1970.

Wylder, Stephen, railfan. Letter to the author, 18 January 1971.

Wylder, Stephen, railfan. Letter to the ICC, 4 May 1970.

\section{Newspapers:}

Des Moines Register.

Des Moines Tribune

New York Times

Wall Street Journal

Serials:

"Aerotrains Presented to Museums," The Rocket, XXV (November-December, 1966), 5.

"Birth of an Era," The Rocket, XV (February 1956), 10.

"Board Meets," The Rocket, XXX (September-October 1970), 2.

"Club-Diners Replace Snack Beverage Cars," The Rocket, XXIX (September-October, 1969), 15. 
"Club-diners Replace Snack Cars on Peoria Trains," The Rocket, XXVI (January-February, 1967), 15.

"Des Moines Day Train in Operation, August 5," Rock Island News Digest, IV (July 1945), 7.

Donovan, Frank, "BCR \& N," The Palimpsest, XLIV (September 1963), 414-424.

Donovan, Frank, "Disaster and Aftermath," The Palimpsest, LXIV (September 1963), 428-433.

Donovan, Frank, "The Great Rock Island Route," The Palimpsest, LXIV (September 1963), 434-438.

Draper, William, "The Rocketing Rock Island," Railroad Magazine, LVI (September 1963), 14-39.

"The Dying Passenger Train," U. S. News and World Report, XLV (October 3, 1958), 36-39.

"Fare Reduction Proves a Success," The Rocket, XVIII (NovemberDecember 1959), 16.

"Fewer-and far between," Business Week, No vol. (September 26, 1964), 117-118, 123.

"Fourth Dining Award," The Rocket, XXVII, (May-June, 1968), 14.

"Futuristic Train Finds a Buyer," Business Week, No vol. (June 26, $1954), 76$.

"Golden State Booked Solid on First High Speed Run," Rock Island Lines News Digest, V (July 1946), 4.

"Golden State Makes Final Run," The Rocket, XXVII (March-April 1968), 12-13.

Hannon, Raymond, "Why Airlines are Winning the Passenger Battle," Railroad Magazine, LII (July 1950), 12-31.

“The Jet Rocket," The Rocket, XVI (February 1957), 2.

"Jet Rocket is Christened," The Rocket, XV (March 1956), 4-5.

"Jet Rocket is Previewed," The Rocket, XIV (June 1955), 4-5.

"John D. Farrington Dies," The Rocket, XX (November-December 1961), 2.

"Lightweight Streamliners go into Suburban Service," The Rocket, XVII (November-December, 1958), 5 .

"Minnesota ... Land of 10,000 Lakes," Rock Island Lines News Digest, V (July 1946), 8.

Moody's Manual of Investments, American and Foreign-Railroad Securities, John S. Porter, editor-in-chief, Moody's Investors Service, 1937; 1950.

Moody's Transportation Manual, Frank J. St. Clair, editor-in-chief, New York: Moody's Investors Service, Inc., 1968.

Morgan, David P., "Santa Fe Calls it Quits," Trains, XXVIII (January $1968), 3-4,12$.

Myrick, David F., "The Strange Story of the El Paso and Southwestern," Trains, XXVI (February 1966), 44-49.

The Official Guide of the Railways and Steam Navigation Lines of the United States, Puerto Rico, Canada, Mexico and Cuba, New York: National Railway Publication Company, XXXVIII (April 1906); LXXIII (June 1940); LXXX (February (1948); LXXXIV (June 1951); LXXXVII (January 1955); LXXXIX (September 1956); XCV (April 1963); XCIX (November 1966); CII (May 1970). 
"Papers Praise Rock Island trains," The Rocket, XXVIII (SeptemberOctober, 1968), 15.

"Passenger Train Adjustments," The Rocket, XXVI (May-June, 1967), 2. "Pa\$\$enger\$" Newsweek, LVI (September 12, 1960), 79-80.

"Peoria Passenger Service Promoted," The Rocket, XXIX (JanuaryFebruary, 1969), 14.

"Peoria Rocket ties together Illinois' Two Largest Cities," The Rocket, XX (May-June 1960), 4-7.

"Petition Commissioners to End Train Runs," The Rocket, XXVI (Nov. ember-December, 1967), 15.

Poor's Manual of the Railroads of the United States, New York: Poor's Railroad Manual Co., 1911; 1914.

"Popular Summer Passenger Tours offered Again," The Rocket, XXVI (July-August, 1967), 14.

"Quad Cities Trains get 'State' cars," The Rocket, XXVII (March-April, 1968 ), 14.

"RDC's that lost their Engines," Trains, XXVI (December 1965), 37.

"Reduce Certain Passenger Fares," The Rocket, XXVII (March-April, 1968), 11.

"Refurbish Des Moines Station," The Rocket, XXVI (September-October 1967), 11.

"Rock Island Sleeping Cars Serve Twin Cities Travelers," The Rocket, XVIII (November-December 1959), 16.

"The Rocket to the Rockies," "The Rocket, XVIII (September-October, 1958), 4-5.

"Sales Agencies Geared to meet needs of Customers," XXIV (MarchApril, 1965), The Rocket, p. 8.

"Sleepers Discontinued," The Rocket, XXIV (July-August, 1965), 14.

"Snack Beverage Cars put on Trains," The Rocket, XXIV (July-August, 1965), 11.

"Stan Freberg, meet Professor Hilton," Trains, XXVI (July, 1966), 11.

"Streamliners Roll Up a Record," Business Week, no vol., (February 19, 1947), 49.

“They're off. .". RI Lines News Digest, V (May 1946), 3-4.

"Train Runs End," The Rocket, XXX (November-December 1970), 15.

Wright, William R., "The Nuisance of passengers," The Nation, CCIV (February 27, 1967), 275, 276. 
Copyright of Annals of Iowa is the property of State of Iowa, by \& through the State Historical Society of Iowa and its content may not be copied or emailed to multiple sites or posted to a listserv without the copyright holder's express written permission. However, users may print, download, or email articles for individual use. 